UDC 637.52: 57.012 .3

\title{
MICROSTRUCTURE OF CANNED BEEF MEAT
}

O. M YAKUBCHAK, doctor of veterinary sciences, professor,

V. T. KHOMICH, doctor of veterinary sciences, professor,

S. I. USENKO, head of the training laboratory,

V. I. KHOMUMENKO, postgraduate student,

M. B. IGNATOVSKAYA, candidate of veterinary sciences, National University of Bioresources and Natural Resources of Ukraine

M. S. KARPULENKO, candidate of veterinary sciences. Ukrainian Resource Research Institute

E-mail:m.ignatovskaya1@gmail.com

The conducted researches found that organoleptic parameters of canned meat producers № 1 , namely, appearance and consistency did not meet the requirements of DSTU 4450: 2005; Manufacturer № 2-appearance, consistency, color of meat; Manufacturer № 3 - appearance, consistency, color of meat; Manufacturer № 4-appearance; Manufacturer № 5 - appearance, consistency. Meat canning manufacturer № 6 was made in compliance with all the rules of formulation and manufacturing technology, was in line with current requirements and served as a control.

Histological studies of experimental canned meat detected the presence of foreign canns in the microstructure of preserves, namely: the presence of fibrous connective tissue, impurities of the fragments of the periosteum, fragments of soy, starch fragments not stated in the formulation.

Ключові слова: beef canned meat, organoleptic studies, histostructure analysis

Introduction. Given the variety of canned meat and the increased requirements for their quality, requirements for improving the control methods of both total production and the quality assessment of finished products carried out by veterinarian doctors are increasing. Meat products at each stage of processing and in the finished form mainly preserve the morphological features of the tissues, which makes it possible to conduct a histostructure analysis to identify the raw material and establish falsification of the finished product.

Analysis of recent researches and publications. Meat and meat products - the main products in the human diet of animal origin - an indispensable source of valuable pro- teins, fats, vitamins, minerals, other vital components. A significant share in the structure of retail turnover belongs to meat, sausages, canned meat, semi-finished products, concentrates, etc. [2].

Food products, sealed in a sealed container and processed at a temperature of about $100^{\circ} \mathrm{C}$, are called canned food.

The meat contained in jars should be juicy and not firm. Pieces of meat during removal from the cans should not collapse and disintegrate, the content of cartilage, tendons, coarse inclusions of connective tissue, lymph nodes and bones is not allowed.

For the production of canned meat use a variety of raw materials, which are conventionally divided into the main and auxiliary. 
The main raw materials include meat and offal of farm animals (large and small cattle, pigs, horses, rabbits and poultry), animal fats, eggs and egg products, milk and dairy products, blood and protein preparations. Auxiliary raw material for canned meat: salting ingredients (salt, sodium nitrite, sugar, ascorbic acid, phosphates) and spices (pepper, nutmeg, bay leaf, onion, garlic, cinnamon, cardamom, spices extracts, etc.) [2, 3 ]

Canned meat canned meat is a product whose use in food does not require additional culinary processing, which allows them to be used in all conditions and in different climatic zones [3].

Purpose. Determination of organoleptic parameters of canned meat from beef of the highest grade and conduct histological studies to identify their composition in accordance with the requirements of the current DSTU 4450: 2005 [2].

Methods. The material for conducting the research served 5 samples of canned meat of one batch made from beef meat of the highest grade according to DSTU 4450: 2005 by six different manufacturers. Organoleptic studies were conducted in accordance with the current GOST 30425-97 [5]. Histological studies were performed according to DSTU 7063: 2009 [5]. Coloring of preparations was carried out by several methods, namely: staining with hematoxylin-eosin, by Van Gyzon, and to identify the starch content, a solution of Lugol was used as a dye $[1,5,6,7,8]$.

Results. During the organoleptic studies of canned meat producers No. 1, it was found that the canned food had the following appearance: meat is cooked with slices, mainly weighing less than $30 \mathrm{~g}$, with available vascular beams and coarse connective tissue; Color and appearance of meat juice in the heated state - light yellow color; The consistency - the meat is not juicy, digested, during the careful removal of the bits of the piece break up; The color of the meat - dark red with a brown tint; Smell and taste - are characteristic of stewed meat with a spice flavor, without any foreign smell and taste.

Consequently, according to the organoleptic parameters, canned food produced by the specified producer did not meet the requirements of the current DSTU by color, appearance and consistency (in normal appearance, the meat is steamed with bits, the pieces do not decompose, basically, weighing not less than $30 \mathrm{~g}$, without cartilage, Vascular bundles and coarse connective tissue).

Histological studies have found that during the study of samples with the help of a small increase $(4 \times 10)$ of the microscope revealed fragments of muscle tissues, which are torn apart and longitudinally (Fig. 1, 2). Between these fragments is an eosinophilic substance. Available congestion of fat cells, which are represented by lipocytes. The pieces of the muscle are surrounded by an eosinophilic substance, which is a consequence of heat treatment.

It should be noted that during the study of the sample under a large increase $(40 \times 10)$, pieces of meat, formed by tufts of muscle fibers. The beads are separated by layers of fibrous connective tissue - a mime, and between the fibers is an endosomal. The winner is extended, it reveals an eosinophilic substance. Muscle fibers are preferably in bundles, tightly arranged. The endosome is sometimes expanded, and there is also an eosinophilic substance, which again can be explained by thermal treatment. Transversal stiffness of muscle fibers is not expressed.

The nuclei in the fibers are not expressed. Separate muscle fibers are fragmented. In individual fibers, transverse cracks are found, which is also the result of heat treatment. There are many eosinophilic granular substances found between the beams of muscle fibers. In transverse sections, muscle fibers have an oval, square, moonlike shape, that is, it indicates their deformation. Is the inclusion of dense fibrous connective tissue in the meat, possibly a ligament or tendon; 


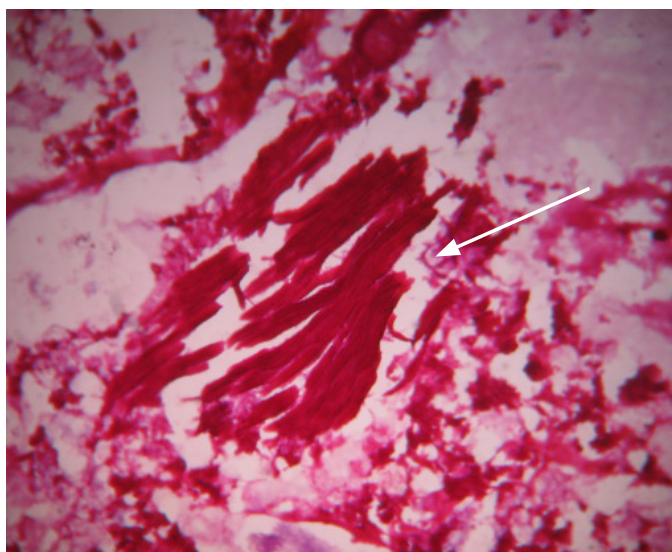

Fig. 1 Fragments of muscle tissues in a longitudinal section. Hematoxylin eosin (4x10)

Their beams are loose due to the heat treatment carried out. Present impurities of the periosteum, namely, in the cut revealed dense fibrous connective tissue, which is categorically not allowed in canned food. Separate fat cells are destroyed, the nuclei are almost non-expressed.

Consequently, such canned foods should not be consumed and consumed in food.

As a result of the research of canned meat products number 2 canned meat had the following appearance: meat stewed in pieces, mainly, weighing less than $30 \mathrm{~g}$, without cartilage, vascular bundles and coarse connective tissue; Color and appearance of meat juice in the heated state - yellow; Consistency - meat is not juicy, digested; During the careful removal of the bits of the piece completely break up; The color of the meat - dark red with a brown tint; Smell and taste - are characteristic of stewed meat with a spice flavor, without any foreign smell and taste.

Consequently, according to organoleptic studies, deviations were found regarding the appearance, consistency, color of the meat (normally the color is from light gray to dark gray or gray with brown and pink shades of different consistency).

Histologic studies under a small magnification (4x10) of a microscope revealed frag-

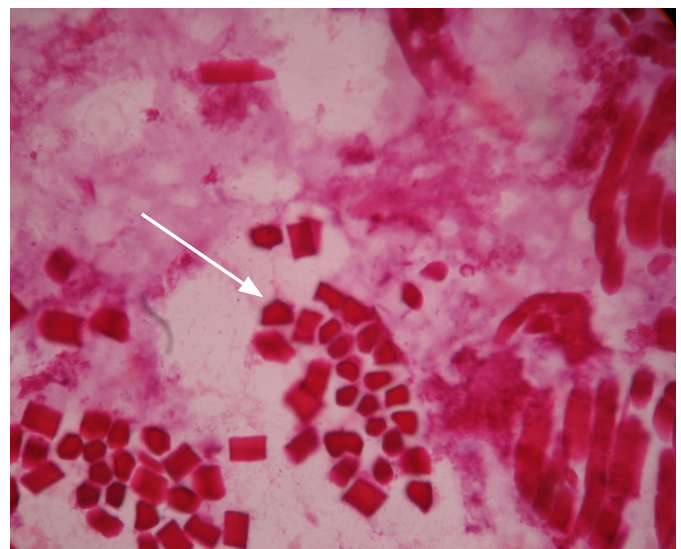

Fig. 2. Fragments of tissue muscles in a transverse section. Hematoxylin eosin $(4 \times 10)$

ments of muscle tissues, which were torn apart and transversely. The pieces of the muscle are surrounded by an eosinophilic substance, which is a consequence of heat treatment. Under a large increase $(40 \times 10)$ it is evident that pieces of meat are formed by bundles of muscle fibers. The nuclei in the fibers are not expressed. Separate muscle fibers are fragmented. In individual fibers, transverse cracks are found, which is also the result of heat treatment.

Consequently, according to the results of histological studies, no deviations from the recipe, but the requirements of the technological instruction for the production of canned are violated.

According to the results of the organoleptic study, canned meat of the producer at number 3 had the following appearance: meat stewed in pieces, mainly, weighing less than $30 \mathrm{~g}$, without cartilage, vascular bundles and coarse connective tissue; Color and appearance of meat juice in the heated state - yellow; Consistency - meat is not juicy, digested; During the careful removal of the bits of the piece completely break up; The color of the meat - brown with a pink tinge; Smell and taste - are characteristic of stewed meat with a spice flavor, without any foreign smell and taste. 


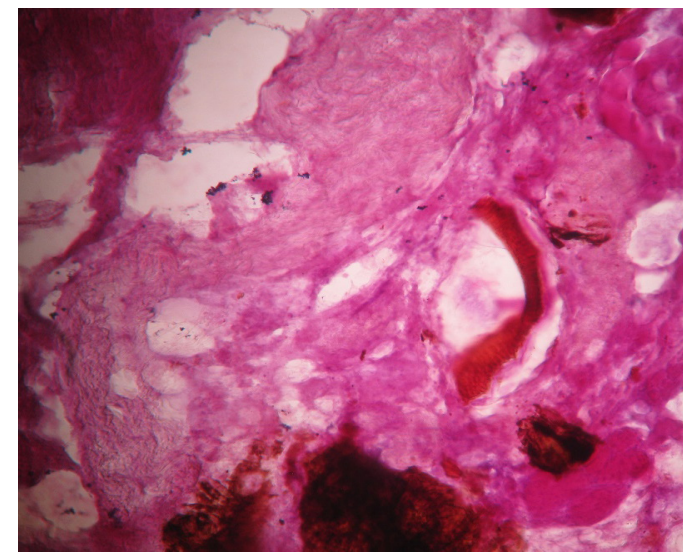

Fig. 3 Canned meat. Fragments of pepper. Hematoxylin eosin

Histologic studies have found that during the examination of samples under a small magnification $(4 \times 10)$ of the microscope, fragments of the muscle of tissues, which were torn apart and transversely, were detected. Between these fragments is an eosinophilic substance. Muscle fibers are loose, between them there is an eosinophilic substance. The color of muscle fibers is not uniform. In the longitudinal section, the muscle fibers adhere tightly; In the fibers are found transverse cracks. The nuclei in the fibers are not expressed. Separate muscle fibers are fragmented. Notable pieces of brown pepper (Fig. 3).

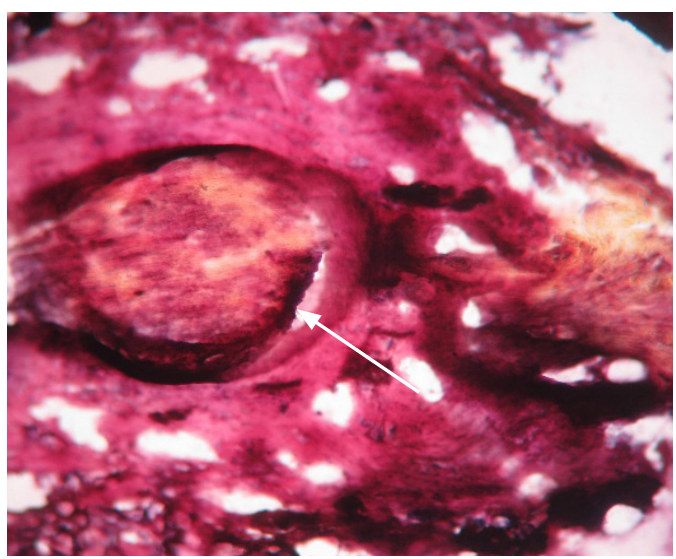

Fig. 4 A fragment of soy protein in minced meat. Dyeing by Van Gizon
Also, during the study, grain of starch and soy protein were detected (Fig. 4, 5).

Consequently, the conducted researches found that the canned food of this manufacturer did not meet the requirements of DSTU in appearance, consistency, color of meat and composition (available fragments of soy protein and starch).

As a result of the study of canned meat of manufacturer No. 4, they had the following appearance: meat stewed in pieces, mainly, weighing less than $30 \mathrm{~g}$, without cartilage, vascular bundles and coarse connective tissue; Color and appearance of meat juice in the heated state - light brown color; Consistency-juicy meat, not digested during careful removal from the cans of the piece do not decompose; The color of the meat is gray with a brown shade; Smell and taste - are characteristic of stewed meat with a spice flavor, without any foreign smell and taste.

Histologic studies have shown that during the study of samples, well-defined beams of muscle fibers, which were separated by a mimetic, were revealed. On the periphery of the beams, a jelly was felted. The bunches of muscle fibers are different in size. Consequently, according to the results of histological studies, deviations in compliance with the recipes during the manufacture of canned meat were not detected.

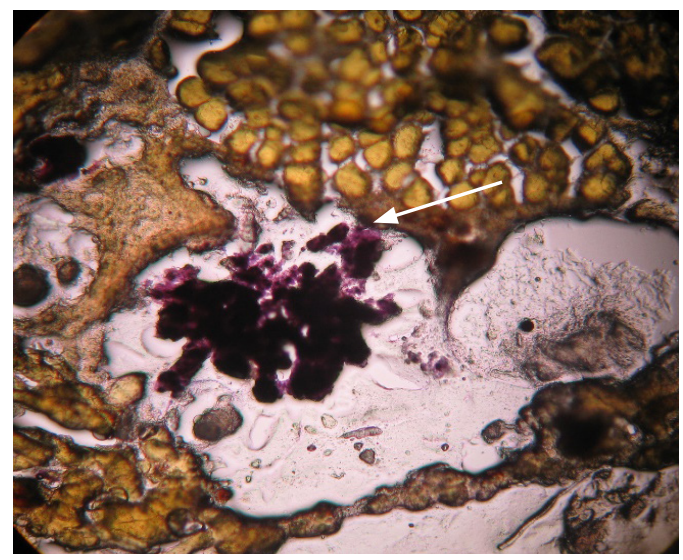

Fig. 5 A fragment of starch grains in minced meat. Dyeing with a solution of Lugol 
According to the results of the organoleptic study of canned meat of manufacturer No. 5, the preserves had the following appearance: meat is stewed in pieces, mainly, weighing less than $30 \mathrm{~g}$, without cartilage, vascular bundles and coarse connective tissue; Color and appearance of meat juice in the heated state - light yellow color; The consistency - the meat is not succulent, digested during the careful removal of the bits of the piece break up; The color of the meat is gray with a brown tint; Smell and taste - are characteristic of stewed meat with a spice flavor, without any foreign smell and taste.

During the histological studies of canned meat on the histocorrelation of fiber bundles in the longitudinal section, the expansion of the membrane, an eosinophilic substance was found in the endosomal. Muscle fibers are fragmented, fragments dense, significant fibrous inclusions of tendons, ligaments are detected. Between the beams - the layers of the transition, on the periphery the connective tissue.

Consequently, during the manufacture of canned meat, meat is used, mainly lowgrade, which characterizes the violation of the formulation, which can be detected only through histological studies.

Meat canning manufacturer № 6 served as a control, which, in all respects, complied with DSTU 4450: 2005 «Canned Meat. Meat is stewed. TU «. According to the organoleptic characteristics of canned products, the appearance of the higher-grade varieties corresponded to the appearance - the meat is stewed in pieces, mainly with a mass of not less than $30 \mathrm{~g}$, without cartilage, vascular bundles and coarse connective tissue; Color - dark gray; Color and appearance of meat juice in the heated state yellow; Consistency - juicy meat, not digested;
During a careful removal from the cans the pieces do not fall apart; Smell and taste - are characteristic of stewed meat with a spice flavor, without any foreign smell and taste.

During the histological studies, a pattern was observed that was characteristic of the meat that was subjected to rubbing, in particular, with a small increase $(4 \times 10)$ of the microscope, fragments of the muscle of tissues, which were torn along and in the waist, were detected. The pieces of the muscle are surrounded by an eosinophilic substance, which is a consequence of heat treatment. Under a large increase $(40 \times 10)$, it is evident that pieces of meat are formed by bundles of muscle fibers. In individual fibers, transverse cracks are found, which is the result of heat treatment.

\section{Conclusions and perspectives.}

1. The organoleptic parameters of canned meat from beef of the highest grade of the manufacturer № 1, namely, appearance and consistency did not meet the requirements of DSTU 4450: 2005; Manufacturer № 2 - appearance, consistency, color of meat; Manufacturer № 3 - appearance, consistency, color of meat; Manufacturer №4-appearance; Manufacturer № 5 - appearance, consistency.

2 According to the results of the conducted research, it was found that when making canned meat of high-grade beef, the formulation has been violated, which results in the presence in the microstructure of foreign non-typical for this type of product of the components.

3. It was established that the preserves of meat producers № 1 and № 3 were the most atypical, namely, the presence of fibrous connective tissue, impurities of the periosteum fragments, soybean fragments, starch fragments.

\section{References}

1. Horalskyi L. P. Osnovy histolohichnoi tekhniky i morfofunktsionalni metody doslidzhen u normi ta pry patolohii / L. P. Horalskyi, V. T. Khomych, O. I. Kononskyi. - Zhytomyr: Polissia, 2011. - 288 s. 
2. Konservy miasni. Miaso tushkovane. Tekhnichni umovy: DSTU 4450:2005. - [Chynnyi vid 01.07.2006 r.]. - K.: Derzhspozhyvstandart Ukrainy, 2005. - 16 s.

3. Metodychni vkazivky dlia studentiv fakultetu veterynarnoi medytsyny ta slukhachiv instytutu pisliadyplomnoi osvity za spetsialnistiu 7.130501 «Veterynarno-sanitarna ekspertyza kovbasnykh vyrobiv i produktiv iz svynyny, baranyny, yalovychyny ta miasa inshykh vydiv zabiinykh tvaryn» / uklad. O. M. Yakubchak, V. I. Khomenko, S. D. Melnychuk. - K.: NAU, 2002. - 70 s.

4. Metodychni vkazivky do vyvchennia dystsypliny «Veterynarno-sanitarna ekspertyza z osnovamy tekhnolohii ta standartyzatsii produktiv tvarynnytstva» / uklad. O. M. Yakubchak, V. V. Vykhovanets, T. V. Taran. - K.: Tsentr IT, 2011. - 31 s.

5. Napivfabrykaty miasni ta miaso-roslynni sicheni. Vyznachannia skladnykiv mikrostrukturnym metodom: DSTU 7063:2009. - [Chynnyi vid 01.01.2010 r.]. - K.: Derzhspozhyvstandart Ukrainy, 2010. - 13 s.

6. Konservы. Metod opredelenyia prombshlennoi sterylnosty: HOST 30425-97 - [Vved. v deistvye 01.01.1998 h yzmenenyia ot 18.10.2016 h]. - M.: Standartynform, 2011. - 16 s. - (Hosudarstvennui standart).

7. Miaso y miasnыe produktы. Metod hystolohycheskoi ydentyfykatsyy sostava: HOST 31479-2012 [Vved. v deistvye 01.07.2013 h yzmenenyia ot 18.07.2016 h]. - M.: Standartynform, 2013. - 12 s. (Hosudarstvennui standart).

8. Miaso y miasnыe produktы. Hystolohycheskyi metod opredelenyia rastytelnыkh belkovыkh dobavok: HOST 31474-2012 - [Vved. v deistvye 01.07.2013 h yzmenenyia ot 18.07.2016 h]. - M.: Standartynform, 2013. - 14 s. - (Hosudarstvennui standart).

9. Miaso у miasnыe produktы. Hystolohycheskyi metod opredelenyia rastytelnыkh uhlevodnыkh dobavok: HOST 31500-2012 - [Vved. v deistvye 01.07.2013 h]. - M.: Standartynform, 2012. - 11 s. - (Hosudarstvennoi standart).

10. Miaso y miasnыe produktы. Opredelenye rastytelnыkh komponentov v sыpuchykh dobavkakh hystolohycheskym metodom: HOST 54368-2011 - [Vved. v deistvye 01.07.2012 h]. - M.: Standartynform, 2012. - 8 s. - (Hosudarstvennui standart).

\section{АНОТАЦІЯ.}

О. М. Якубчак, В. Т. Хомич, С. І. Усенко, В. I. Хомутенко, М. В. Іенатовська, М. С. Карпуленко. Мікроструктура консервів м'ясних із яловичини//Біоресурси і прирокористування. - 2017. - 9, №3-4. - С.62-67.

Проведеними дослідженями встановлено, що органолептичні показники консервів м'ясних виробника № 1, а саме, зовнішній виаляд $і$ консистениія не відповідали вимогам ДСТУ 4450:2005; виробника № 2 - зовнішній виаляд, консистениія, колір м'яса; виробника № 3 - зовнішній вигляд, консистениія, колір м'яса; виробника № 4- зовнішній виаляд; виробника № 5 - зовнішній вигляд, консистениія. М'ясна консерва виробника № 6 була виготовлена з дотриманням усіх правил рещептури та технологї виготовлення, відповідала чинним вимогам та слугувала контролем.

Гістологічними дослідженнями дослідних консервів м'ясних виявлено присутність у мікроструктурі консервів сторонніх включень, а саме: присутність волокнистої сполучної тканини, домішок фрагментів окістя, фрагменти сої, фрагменти крохмалю, шо не заявлено в рецептурі.

Ключові слова: консерви м'ясні із яловичини, органолептичні дослідження, гістоструктурний аналіз

\section{АННОТАЦИЯ}

О. Н. Якубчак, В. Т. Хомич, С. И. Усенко, В. И. Хомутенко, М. В. Игнатовская, М. С. Картуленко. Микроструктура консервов мясных из говядины//Биоресурсы и природопользование. - 2017. - 9, №3-4. - C.62-67.

Проведенными исследованиями установлено, что органолептические показатели консервов мясных производителя № 1, а именно, внешний вид и консистениия не соответствовали требованиям ДСТУ 4450: 2005; производителя № 2 - внешний вид, консистениия, ивет мяса; производителя № 3 - внешний вид, консистениия, иветмяса; производитела № 4 - внешний вид; производителя № 5 - внешний вид, консистениия. Мяснъе консервы производителя №6 были изготовлена с соблюдением всех правил рецептуры и технологии изготовления, отвечала действуюиим требованиям и служсила контролем.

Гистологчческими исследованиями исследовательских консервов мясных обнаружено присутствие в микроструктуре консервов посторонних включений, а именно: присутствие волокнистой соединительной ткани, примесей фрагментов надкостницы, фрагменты сои, фрагменты крахмала, не заявленные в рецептуре.

Ключевые слова: консервы маснье из говядины, органолептические исследования, гистоструктурный анализ 